\title{
MULTI-PHASE, SUB-MICROMETER SILICATE, SULFIDE \& FLUID INCLUSIONS IN DIAMONDS: EXPRESSIONS OF METASOMATISM EVIDENCED IN PERIDOTITES AND ECLOGITES
}

\author{
Logvinova, A.M. ${ }^{1}$, Wirth, R. ${ }^{2}$, Sobolev, N.V. ${ }^{1}$, and Taylor, L.A. ${ }^{3}$ \\ ${ }^{1}$ Institute of Geology and Mineralogy, Siberian Branch of Russian Academy of Science, Novosibirsk, Russia \\ ${ }^{2}$ Helmholtz Centre Potsdam GFZ German Research Centre for Geosciences, Exper.Geochem \& Mineral Physics, Potsdam, Germany. \\ ${ }^{3}$ Planetary Geosciences Institite, Department of Earth \& Planetary Sciences University of Tennessee, Knoxville, TN 37996 USA
}

\section{INTRODUCTION}

Sub-micrometer inclusions in the central zones of diamonds are an important source of information on the environment and the metasomatic mantle fluids associated with diamond crystallization. Such minute inclusions reveal the nature of the multiphase mineral and fluid assemblages (Logvinova et al., 2008). Commonly metasomatic agents include carbonatite, silicate melt, $\mathrm{KCl}$ brine, and $\mathrm{C}-\mathrm{O}-\mathrm{H}-\mathrm{N}$ fluids. Mineral inclusions indicate that diamonds related to two principal host-rock types occurring in the deep lithosphere, ultramafic peridotite (U,P) and eclogite (E). Peridotitic diamonds are formed in an environment dominated by forsteritic olivine and $\mathrm{Fe}-\mathrm{Ni}$ sulfide and eclogitic diamonds - by omphacite and Fe-sulfide. Investigations of silicate mineral assemblages in diamonds and mantle xenoliths suggest that in some areas, the upper mantle was depleted in its low-temperature components by partial melting and later enriched by metasomatism (Harte, 1987). Although most studies of inclusionsin diamonds focus on the silicate assemblages, some silicate inclusions have been metasomatised by the co-existing fluid; however, sulfide minerals can be very useful in understanding the processes of partial melting and metasomatic enrichment. Sulfide inclusions in diamonds provide unique information on the distribution of chalcophile elements in the mantle. Sulfide inclusions are the most common of the mineral inclusions in diamonds (Meyer, 1987). Commonly sulfide phases occur surrounding olivine, garnets, pyroxenes, or exist as discrete sulfide inclusions (Daines and Harris, 1995; Yefimova et al., 1993); the sulfide inclusions typically display rosette fractures, with graphite and chalcopyrite observed along the cracks.

Based largely on petrographic and chemical characteristics of sulfide minerals in mantle-derived xenoliths, it has been suggested that they developed from a quenched immiscible sulfide melt, possibly during partial melting. However, since $\mathrm{S}, \mathrm{Fe}, \mathrm{Ni}, \mathrm{Cu}$, and $\mathrm{Co}$ may be added to the mantle during metasomatism, sulfides may also be formed as a result of metasomatic enrichment.

Sulfides are the main reservoir for chalcophile elements in the mantle, and as such, contain invaluable data on the geochemistry of this largely unsampled portion of the Earth. This study provides new data for sulfide inclusions in different diamond suites. We have studied coexisting multiphase assemblages of silicate-sulfide-graphite, and fluid sub-micrometer inclusions in the central zones of Yakutian octahedral diamonds. The aim on this study is to better understand the relationship between sulfide, silicate, and fluid inclusions and identify the processes by which sulfide minerals formed in the mantle.

\section{SAMPLES AND ANALITICAL METHODS}

Nine diamond samples from the Internatsionalnaya kimberlite pipe and three alluvial diamonds from northeast Siberian placer deposits were selected for detailed study. In their centers, they contain assemblages of numerous micron and sub-micron inclusions (Fig.1).

The diamonds were polished along dodecahedral planes, in order to expose inclusions for analysis and to produce central sections of crystals for study of their growth history. All samples were examined using reflected-light

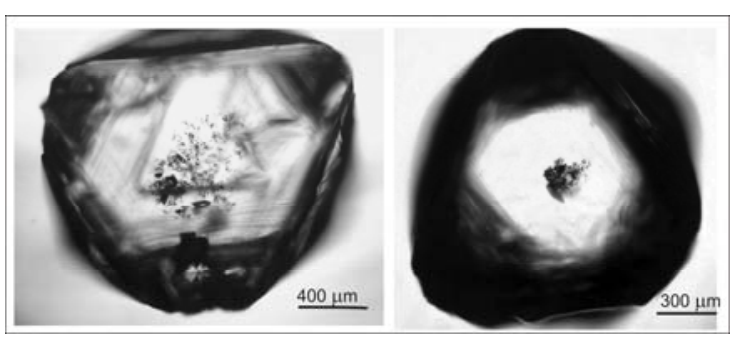

Fig.1. Photomicrographs of diamonds, contained micro- and sub-micro-inclusions of silicate-sulfide-fluid assemblages. 


\section{$10^{\text {th }}$ International Kimberlite Conference, Bangalore - 2012}

microscopy to identify sulfide grains and examine their relationship to the enclosing minerals. Estimates of the relative proportions of the sulfide phases were made from back-scattered electron microscopy.

The internal structure of the polished diamonds was imaged using cathodoluminescence (CL), with an energyloss spectrometer OXFORD LEO-1430VP at the IGM of the SB RAS (Novosibirsk) and at the University of Tennessee. Major-element compositions of silicate and sulfide micro-inclusions were determined with a fully automated CAMECA SX-50 electron microprobe (EMP) at the University of Tennessee. The EMP analytical conditions employed an accelerating potential of $15 \mathrm{kV}$, with $20 \mathrm{nA}$ beam current, $5 \mu \mathrm{m}$ beam size, and standard PAP procedures. Counting times were $20 \mathrm{sec}$.

To identify nanometer scale phases, which composed multiphase sub-micron-inclusions, we used transmission electron microscopy (TEM) techniques, including electron diffraction; analytical electron microscopy, with elemental mapping; electron energy-loss spectroscopy (EELS); and high-resolution electron microscopy. TEM foils were prepared from the central zones of the diamonds using the focused ion beam (FIB) (Wirth, 2004).

\section{RESULTS}

Five of the diamonds contained olivine-sulfide micron- and sub-micron-inclusion assemblages, all U-type diamonds; four others contained omphacitic clinopyroxene, rutile, garnet, and sulfide micron-inclusions, indicative of E-type diamonds. Alluvial diamond inclusions were from both U- and E-types, and range between $50 \mathrm{~nm}$ and $6 \mu \mathrm{m}$ in size. They possess an imposed diamond morphology. These inclusions occur in the matrix-core and intermediate-growth zones, as revealed by cathodoluminescence imaging (Fig.2).
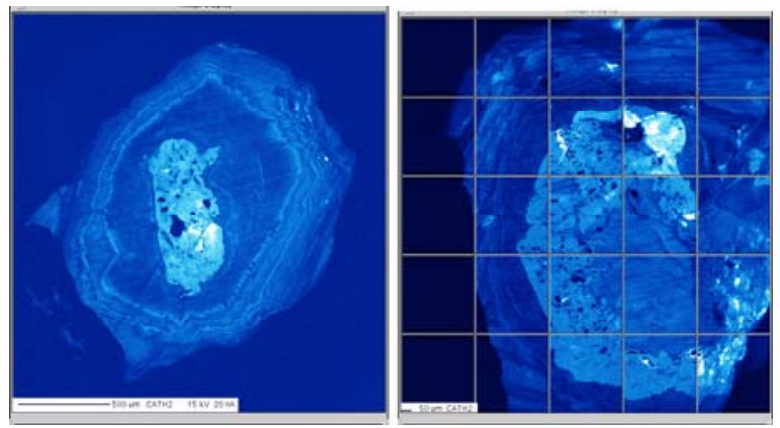

Fig.2. CL images revealing the internal structure of diamonds from Internatsionalnaya pipe (Yakutia). Assemblages of micro- and sub-micro-inclusions occur in the isolated growth zone of diamond.

They present the multiphase micron- and sub-microninclusions, consisting of silicates, sulfides, graphite, and fluids. The silicates are represented by olivine (U-type) and omphacitic clinopyroxene (E-type), with sulfides [monosulfide-solid solution (Mss)], graphite, $\mathrm{KCl}$, and quenched materials, rich in $\mathrm{S}, \mathrm{Ca}, \mathrm{Pb}, \mathrm{K}$, and $\mathrm{Cl}$. Olivineinclusions represent the high magnesian varieties. Compositions of olivines range in mg\# (molar $[\mathrm{Mg} / \mathrm{Mg}+\mathrm{Fe}] \mathrm{x} 100$ ) from 93 to 94 . Olivines occur as an intergrowth with sulfides. Sulfides are characterized by lamella texture of two phases: Ni-rich (pentlandite) and Fe-rich (pyrrhotite), as a result of exsolution of Mss upon cooling. The $\mathrm{Ni} /(\mathrm{Ni}+\mathrm{Fe})$ ratio of their bulk composition in these peridotitic diamonds is $0.39 \pm 0.04$. A large number of fluid bubbles were observed inside sulfide-phases, in contact with graphite, $\mathrm{KCl}$, and quenched materials. As confirmed by recent experimental results, sulfides might serve as a possible redox agent. In peridotitic diamonds from the Internatsionalnaya pipe, wüstite, millerite, chalcopyrite, and olivine have been identified by electron diffraction and chemistry at the contacts of sulfide and graphite. In addition, fluid bubbles were identified as changing absorption contrasts due to density fluctuations caused by the electron beam. In sample Im-72, micron-inclusions occur, consisting of two phases: silicate (olivine) and sulfide (Mss). This specific texture is interpreted to have formed by exsolution processes during cooling (Fig.3).

Clinopyroxenes in several of the diamonds are omphacitic in composition, with elevated $\mathrm{Al} 2 \mathrm{O} 3$ (up to 12.4 wt.\%) and $\mathrm{Na} 2 \mathrm{O}$ (up to 6.2 wt.\%) contents, but relatively low Mg- and Ca-numbers. Omphacites occur as intergrowths with Ni-poor sulfides. Rutile has been identified in association with omphacite. In sample Im-47, isolated sulfides are represented by oriented intergrowths of sulfide and graphite, which appear homogeneous in composition and contain fluid bubbles. EDX spectra of these sulfide inclusions are high in Fe. Based upon their apparent homogenous chemistry and diffraction patterns, we assume that these sulfide sub-micron-inclusions are actually un-exsolved monosulfide solid solution (Mss). The $\mathrm{Ni}$-poor Mss compositions ( $\mathrm{Ni} / \mathrm{Ni}+\mathrm{Fe}$-ratio is $0.07 \pm 0.02$ )

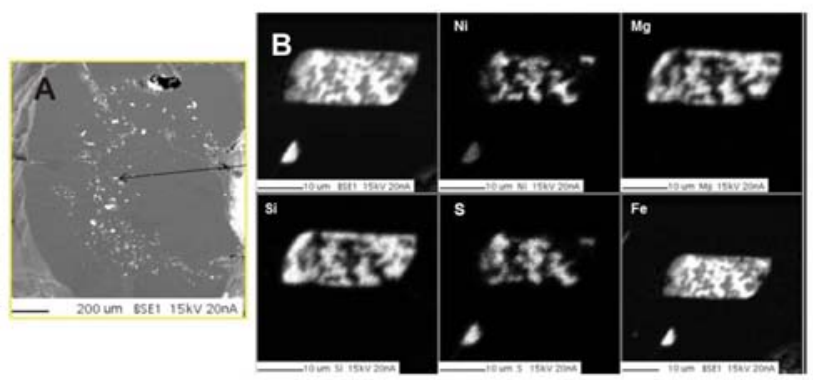

Fig.3. (A) Backscattered electron image (BSE), showing the localization of micro- and sub-micro-inclusions in Internatsionalnaya diamond (Im-72); (B) X-ray element distribution map of one of the inclusions: bright greys indicate high concentrations and dark greys indicate low concentrations. This image shows the exolution features of silicate-sulfide melt. 


\section{$10^{\text {th }}$ International Kimberlite Conference, Bangalore - 2012}

extend into the pyrrhotite field. The fluid is rich in $\mathrm{Cl}, \mathrm{K}, \mathrm{S}$, $\mathrm{H}$, and carbonate and was found in close association with mineral sub-micron-inclusions of eclogite and peridotite parageneses.

Sulfide grains in the alluvial diamonds are located mainly in the nucleated cores of the diamond-matrix, as "black clusters", associate with high-silica mica, $\mathrm{KCl}$, and fluids. The textures of both the sulfide grains and the fluid inclusions suggest that they formed during growth of the enclosing diamond crystals. The size of these inclusions varies from 5 to $200 \mathrm{~nm}$. The minute sulfide inclusions are homogeneous in composition within one sample, and accompanied by numerous fluid phases . The $\mathrm{Ni} /(\mathrm{Ni}+\mathrm{Fe})$ values reached up to $0.75 \pm 0.02$.

\section{DISCUSSION AND CONCLUSIONS}

Sulfide inclusions commonly display intense subsolidus exsolution into various low-temperature phases. Taylor and Liu (2009) have shown that macro-inclusions of sulfide minerals in diamonds display major intergrowths of pyrrhotite and pentlandite, with lesser amount of chalcopyrite, which are a typical assemblage formed by subsolidus exsolution of an $\mathrm{Fe}-\mathrm{Ni}-\mathrm{Cu}-\mathrm{S}$ monosulfide solid solution (Mss). However, sub-micrometer Ni-rich or Nipoor, centrally located sulfide inclusions appear to be homogeneous in composition or have a lamellar structure imaging the initial stage of an exsolution process. In all cases, they are accompanied by fluids, $\mathrm{KCl}$, and graphite. There are at least two explanations to these observations: 1 ) sulfide precipitation may have occurred directly from a sulfate-bearing, possibly subduction-related fluid (Jugo et al., 2005); or 2) the sulfur transportation occurred through the lithospheric mantle as a dissolved component in mobile metasomatic fluids, before separation of an immiscible sulfide melt (Gaetani and Grove, 1999). Indeed, Wentorf (1974) studied the reactions of graphite with different sulfides at $1400-1600^{\circ} \mathrm{C}$ and $6 \mathrm{GPa}$ and concluded that immiscible sulfide melts correspond to graphite-forming solvents.

Schrauder and Navon (1994) have reported on melts of hydrous-silicic (rich in water, $\mathrm{Si}, \mathrm{Al}$, and $\mathrm{K}$ ), carbonatitic (rich in carbonate, $\mathrm{Mg}, \mathrm{Ca}$, and $\mathrm{K}$ ), and saline (rich in water, $\mathrm{Cl}$, and $\mathrm{K}$ ) components. However, the apparent coexistence of sulfides with graphite, $\mathrm{KCl}$, fluids, and possible carbonate phases at the time of diamond nucleation could be interpreted to indicate that silicate-sulfide melts can also coexist. Sulfur-rich micro-inclusion compositions might represent the entrapment of $\mathrm{Ni}$-rich sulfide melt or mixtures between an Mss phase and a sulfur vapor. These could be in equilibrium at high temperatures together with silicate or carbonate HDFs (Lorand and Gregoire, 2006).

These observation adds yet another set of conditions to the diamond-forming fluid system, thus enlarging the range of trace elements that may be transported by such fluids. These preliminary results assume that silicate-sulfide sub- micron inclusions in diamonds have been trapped at the earliest stage of their crystallization during interaction of incipient mantle fluids and the diamond-host protoliths (peridotites and eclogites). This fluid may have consisted of a carbonatitic component and immiscible Fe-Ni-sulfide melts. Introduction of this fluid assemblage into a reduced and refractory environment may have been accompanied by a thermal pulse, which might have created the conditions to promote the nucleation and growth of diamond. The results reported here on the complex character and composition of silicate-sulfide-saline-graphite micro-inclusions in diamond testify to the significant role of deep metasomatic processes in the formation of diamonds.

\section{References}

Deines, P., Harris, J.W. (1995). Sulfide inclusion chemistry and carbon isotopes of African diamonds. Geochimica et Cosmochimica Acta, 59, 3173-3188.

Gaetani, G.A., Grobe, T.L. (1999). Wetting of mantle olivine by sulfide melt: implications for $\mathrm{Re} / \mathrm{Os}$ ratios in mantle peridotite and late-stage core formation. Earth and Planetary Science Letters, 169, 147-163.

Harte, B. (1987). Metasomatic events recorded in mantle xenoliths: an overview. In: Nixon P.H. (Ed.) Mantle xenoliths. England, John Wiley and Sons Ltd, 625-640.

Jugo, P.J., Luth, R.W., Richardson, J.P. (2005). An experimental study of thr sulfur content in basaltic melts saturated with immiscible sulfide or sulfate liquids at $1300^{\circ} \mathrm{C}$ and $1.0 \mathrm{GPa}$. Journal of Petrology, 46, 783-798.

Logvinova, A.M., Wirth, R., Fedorova, E.N., Sobolev, N.V. (2008) Nanometre-sized mineral and fluid inclusions in cloudy Siberian diamonds: new insights on diamond formation. Eur. J. Miner., 20, 317-331.

Lorand, J.P. and Gregoire, M. (2006). Petrogenesis of base metal sulphide assemblages of some peridotites from the Kaapvaal craton (South Africa). Contrib. Miner. Petrology, 151 (5), 521-538.

Meyer, H.O.A. (1987) Inclusions in diamonds. In: Nixon P.H. (Ed.) Mantle xenoliths. England, John Wiley and Sons, 501522.

Schrauder, M. and Navon, O. (1994). Hydrous and carbonatitic mantle fluids in fibrous diamonds from Jwaneng, Botswana. Geochimica et Cosmochimica Acta, 58 (2), 761-771.

Taylor, L.A., Liu,Y. (2009). Sulfide inclusions in diamonds: not not monosulfide solid solution. Russian Geology and Geophysics, 50 (12), 1201-1211.

Wirth, R. (2004). Focused Ion Beam (FIB): A novel technology for advanced application of micro- and nanoanalysis in geosciences and applied mineralogy. Eur. J. Miner., 16, 863876.

Wentorf, R.H. (1974). Diamond formation at high pressures. Adv. High Press. Rev., 4, 249-281.

Yefimova, E.S., Sobolev, N.V., Pospelova, L.N. (1983) Sulfide inclusions in diamonds and specific features of their paragenesis. Zap. Vses. Miner.Obshschest., 112, 300-310 (in Russian). 